\title{
Formation of bilingual competence of future teachers of preschool and primary education in the Crimea
}

\author{
E.E. Abibullaeva ${ }^{1 *}$ \\ ${ }^{1}$ Department of Preschool Education and Pedagogy of the State Budgetary Educational Institution of \\ Higher Educational of the Republic of Crimea 'Crimean Engineering and Pedagogical University \\ named after Fevzi Yakubov’, Simferopol, Russia
}

\begin{abstract}
The problem of specially trained bilingual teachers remains very relevant for the educational institutions of Crimea. On the one hand, the needs of society, parents, ready to train and educate children in preschool and primary educational institutions of Crimea are growing. On the other hand, there is a problem in the level of knowledge of the state, native Crimean Tatar language of preschool children, and from the third side - the preparation of qualified bilingual teachers. The researches of V.F. Gabdulkhakov, A.M. Gareeva, M.T. Gizzatullina, R.R. Devletov, L.L. Salekhova, F.F. Harisov, Ch.M. Harisova etc. are dedicated to the problems of the preparation of a bilingual teacher in the conditions of developing Russian-national bilingualism in Russia. Substantive studies on this problem were conducted abroad by R. Aliev, N. Kazhe, M. Siguan, U.F. Makki, E. Yu.Protasova, N.M.Rodina and others.
\end{abstract}

\section{A problem statement}

The problem of preparing a bilingual teacher in Crimea is very relevant. Judging from the experience, based on the needs of parents, showed the necessity to create groups and classes with the Crimean Tatar, Russian languages of instruction both monolingual and bilingual.

Thus, in Crimea at the level of preschool education, bilingual groups with the Crimean Tatar and Russian languages of instruction were created and function. In the elementary school - classes with the Crimean Tatar and Russian languages of instruction. In connection with this there was a necessity for preparing teachers who speak Crimean Tatar and Russian languages. The selection of specialists of preschool education who speak Russian does not cause any difficulty, but it is difficult to find a teacher of the Crimean Tatar language who knows special terms.

*Corresponding author: eniseabibulla@mail.ru 


\subsection{The objective of the work}

The preparation of a bilingual teacher requires separate, conceptual and scientificmethodological justification. Although the preparation of teachers at the department of "preschool education" and "primary education" with the right to teach in the Crimean Tatar language has been conducted for a number of years at the Crimean Engineering and Pedagogical University and assumes the formation of the bilingual competence of future teachers.

\section{Results of the research}

Preparation of bilingual teachers was considered in the surveys of Russian scientists. V.F. Gabdulkhakov disclosed the technologies for the development of speech activity in conditions of bilingualism [1], L.L. Salekhova based on a systematic approach, designed a didactic system of bilingual education for future teachers. According to the author's system, L.L. Salekhova's structure of bilingual subject competence includes subject, language, general pedagogical and intercultural components [2]. Sociologist G.M. Gizzatulina defined the ways of preparing a teacher in the framework of the bilingualism model in the system of general secondary education of a multicultural society by the example of the Republic of Tatarstan and Belgium [3], F.F. Harisov revealed the problem of preparing teachers for the national schools of the Republic of Tatarstan, emphasizing the quality of teacher training [4].

In Crimea, the theoretical and methodological foundations for the training of future teachers of primary classes in the Crimean Tatar language in conditions of the trilingual linguistic environment were studied and substantiated by R.R. Devletov. The Crimean scientist developed a model of trilingual teaching of disciplines of the linguistic and didactic cycle in the high pedagogical educational institution [5].

In the foreign scientific literature, the preparation of pedagogical specialists in conditions of bilingual education is reflected in the works of M. Siguan, U.F. Makki. French researchers, considering the preparation of the teaching staff, note the preparation of a teacher for bilingual education or the advance training of the already working teacher. The authors emphasize that a teacher working in the area of bilingual education should acquire pedagogical competence or specialized competence in the subject or group of subjects that he teaches [6].

Ways and methodical recommendations for special preparation of teachers for bilingual preschool educational institutions on the example of foreign and Finnish experience are disclosed by E.Yu. Protasova and N.M. Rodina.

Taking into account the greatest ideological proximity of the situation of Canada, Estonia and Latvia in the problem of bilingual education, we turned to the survey of the author's work by F. Genesee, J. Bolter, B. Komodi, etc. In the "Handbook of Language Immersion", the authors consider bilingual education in the program of language immersion as mastering functional skills in two languages ( $\mathrm{K} 1$ and $\mathrm{K} 2$ ), and in some cases - in three languages. Preparation of teachers provides teacher's substantive training in one of the languages [7].

The Latvian scientist, Doctor of pedagogy, the director of one of the leading Riga gymnasiums R. Aliev and master of pedagogy N. Kazhe have developed methodological recommendations and guidelines for the preparation of a bilingual teacher, based on the preparation of bilingual teachers with sufficient language competence within the frame of their subject matter [8].

In Crimea, the formation of bilingual competences of future teachers is carried out in the specialty of "preschool education" and "primary education" of the Crimean Engineering and Pedagogical University. Preliminary analysis of curricula and attended classes showed 
that future teachers of preschool and primary education are mainly form their language component of bilingual competence. There are difficulties in the formation of subject competence in the Crimean Tatar and Russian language. This is due to the shortage of teachers who are ready to provide teaching of the academic disciplines (private methods) in bilingual regime and in the Crimean Tatar language.

Methods of research: theoretical methods: analysis of (sources on the research problem), comparison of the experience of preparation of bilingual teachers in pedagogical universities of Russia and abroad.

Empirical methods: questioning of students of preschool and primary education on readiness to receive and carry out education in two languages.

The surveys were based on: academic groups of second year students of the specialty "preschool education" and "primary education" of the faculty of psychology and pedagogical education of the Crimean Engineering and Pedagogical University.

Research Methods: for conducting a questionnaire survey, the methodology of A.I. Prigozhin "Matrix of Organizational Problems" was adapted.

Crimean Tatar people after returning from the deportation to their historical homeland Crimea have been reviving the system of national education for 30 years. During this period, the regulatory and legal framework has changed several times, as a whole, the state, thus in particular, in the field of education from the Soviet to the Ukrainian, from the Ukrainian to the Russian, and there are many unresolved issues. One cannot deny the dynamics in the development of education in the Crimean Tatar language, as well as in the Crimean Tatar-Russian languages in Crimea from the end of the XXth century to the present day. According to the Ministry of Education, Science and Youth of the Republic of Crimea in the academic year 2017-2018 there are 7 municipal educational institutions with the Crimean Tatar language of instruction, 4 with Russian and Crimean Tatar languages of instruction and 5 educational institutions that changed the status of the school from the Crimean Tatar language of instruction to general educational institution (without defining the language of instruction) [9].

There are also in Crimea two preschool educational institutions with the Crimean Tatar language of instruction and upbringing (Sarybash village, Pervomaysky district and "Sevinch" in Belogorsk district), since 2014 groups with Russian and Crimean Tatar languages of instruction have been created in Simferopol and Simferopol district.

Thus, based on the desire of parents and public in Crimea at the level of preschool education, groups with the Crimean Tatar and Russian languages of instruction have been created and are functioning, and classes with the Crimean Tatar and Russian languages of instruction have been created for primary and general secondary schools. In connection with this there was a necessity for preparing teachers able to speak Crimean Tatar and Russian languages. Selection of specialists of preschool education able to speak Russian language does not cause any difficulty, but those with the Crimean Tatar language and a good command of special terminology - causes complexity. Preparation of bilingual teachers, as noted above, is conducted in the specialty of "preschool education" and "primary education" of the Crimean Engineering and Pedagogical University. According to the "Concept of bilingual education in a pedagogical university," developed by L.L. Salekhova, at the strategic level, the main goal of bilingual education in the university is the formation and development of the bilingual subject competence of future teachers. Substantial filling of this competence in the opinion of L.L. Salekhova includes the following structural composition: 1) the subject component; 2) language; 3) general pedagogical; 4) intercultural [2].

1. The subject-matter component shows the uniqueness of the curricula disciplines studied in the bilingual regime, and is determined by the level of mastering of the substantive content included. 
2. The language component includes common linguistic and speech competence and a good command of the subject terminology in the field of a specific discipline.

3. The general pedagogical (methodological) component includes pedagogical competence as a synthesis of knowledge, pedagogical skills and professional abilities adequate to a certain type of situations or situational tasks.

4. The intercultural component reflects the student's ability to carry out social interaction in a multicultural society and represents the realization of the idea of multicultural education and upbringing.

The analysis of curricula of the specialty "preschool education" and "primary education" of the Crimean Engineering and Pedagogical University and attended classes showed that the content of the academic disciplines is aimed at the formation of 3 components of the bilingual subject competence of future teachers, namely: linguistic, general pedagogical and intercultural. The general pedagogical and intercultural component of this competence provides for their formation in Russian, and the language component at the students' choice in the Crimean Tatar and Russian languages [2].

In the course of writing the article, we conducted a questionnaire survey among the 2nd year students of the specialty "preschool education" (23 respondents) and "primary education" (19 respondents) according to the adapted methodology of A.I. Prigozhin [10] for determining students' readiness for bilingual education and choice of languages of instruction. Among the root problems there was the identification of students' readiness for bilingual education. Starting from the second year they have the opportunity to choose a cycle of language disciplines in the Crimean Tatar, Russian or Ukrainian languages for their in-depth study, which contributes to the formation of the language component of the bilingual subject competence of future teachers.

The analysis of the questionnaires showed the following results: $13 \%$ of students of the "preschool education" specialty are ready to receive monolingual education in Russian while $87 \%$ - in two languages, $5 \%$ of students of "primary education" specialty are ready to receive monolingual education in the Crimean Tatar language, 95\% - in two languages. The root question of our questionnaire survey was in what languages the future teachers wanted to be taught? Having analyzed the questionnaires of the 2nd year students of the specialty "Preschool and Primary Education", we identified the potential relevance in the implementation of the following education models in two languages (Table 1).

Table 1. Analysis of the results of the survey of the question of language training of university students.

\begin{tabular}{|l|l|l|l|l|l|l|l|}
\hline \multicolumn{1}{|c|}{ Specialty } & \multicolumn{7}{c|}{ Selection of languages of instruction } \\
\hline & year & $\mathrm{R} / \mathrm{C}$ & $\mathrm{C} / \mathrm{U}$ & $\mathrm{R} / \mathrm{U}$ & $\mathrm{R} / \mathrm{E}$ & $\mathrm{C} / \mathrm{E}$ & $\mathrm{U} / \mathrm{E}$ \\
\hline $\begin{array}{l}\text { Preschool } \\
\text { education }\end{array}$ & 2 & $86 \%$ & $6.6 \%$ & $6.6 \%$ & $0.9 \%$ & -- & - \\
\hline $\begin{array}{l}\text { Primary } \\
\text { education }\end{array}$ & 2 & $71.7 \%$ & $11.5 \%$ & $5 \%$ & $0.8 \%$ & $11 \%$ & - \\
\hline
\end{tabular}

(R / C - Russian and Crimean Tatar, C / U - Crimean Tatar and Ukrainian, R / U - Russian and Ukrainian, R/E - Russian and English, C/E - Crimean Tatar and English, U/E - Ukrainian and English)

The questionnaire survey showed the readiness of future teachers to receive bilingual education in Russian and Crimean Tatar (86\% and 71.7\%), Crimean Tatar and Ukrainian (11.5\% and 6.6\%), Crimean Tatar and English (11\%), Russian and Ukrainian $(6.6 \%$ and $5 \%)$, Russian and English $(0.9 \%$ and $0.8 \%)$. In conditions of globalization, the most interesting is the preferential choice of the students of state languages of Crimea.

The formation of the language competence of the 2 nd and 3rd year students is carried out within the framework of the cycle of philological disciplines, namely: the specialty "preschool education" - the state languages of Crimea (Crimean Tatar, Crimean Tatar, Ukrainian), theory and methods of teaching Crimean Tatar, Russian or Ukrainian language, 
folklore (Crimean Tatar, Russian, Ukrainian), children's literature (Crimean Tatar, Russian, Ukrainian), expressive reading (Crimean Tatar, Russian, Ukrainian); on the specialty "primary education" - the state languages of Crimea (Crimean Tatar, Crimean Tatar, Ukrainian), language teaching methods (Crimean Tatar, Russian, Ukrainian), the communicative course of the language (Crimean Tatar, Russian, Ukrainian), speech development methods (Crimean Tatar, Russian, Ukrainian).

Thus, the linguistic component of bilingual subject competence includes the formation of a common linguistic and speech competence, reflects the totality of knowledge and skills obtained in various aspects of Russian, Crimean Tatar and Ukrainian languages and types of speech activity (listening, reading, speaking, writing, translating) as well as the general ability of the future teacher to adequately use the language in prepared and unprepared speech, mastering the language of the specialty. There are difficulties in forming subject competence in the Crimean Tatar and Russian languages. This is due to the shortage of teachers who are ready to provide teaching of the subjects (private methods) in the bilingual regime.

\section{Conclusions}

Thus, on the basis of establishing integrative links between the components of the bilingual subject competence of the future teacher, the linguistic one can be interpreted as the leading one, which ensures the successful professional activity of a bilingual teacher in preschool and primary education. Taking into consideration the willingness of students to receive bilingual education, and then carry out pedagogical activities in bilingual preschool and general education institutions, the desire of parents to educate bilingual children as the ways to preserve and develop their native language (for example Crimean Tatar), it is necessary to solve the problem of the formation of the subject component of a bilingual teacher. Preparation of a bilingual teacher is possible within the framework of bachelor's degree or additional professional education (advanced training course, retraining) in subjects or a group of subjects.

\section{References}

1. V.F. Gabdulhakov, Modern language communication and technology of development of speech activity in the conditions of bilingualism, 207 (1999)

2. L.L. Salekhova, Bilingual education in the teacher training system, 172 (2006)

3. G.M. Gizzatullina, Development of bilingualism in a modern school (general education) school of a multicultural society, 146 (1999)

4. F.F. Harisov, Regional education system: state and evolution strategy, 544 (2005)

5. R.R. Devletov, Teoretiko-methodical bases of training of the future teachers of initial classes to the Crimean Tatar language in the conditions of a trilingual language environment, 43 (2012)

6. M. Siguan, U.F. Makki, Education and bilingualism, 184 (1990)

7. F. Zhenese, Zh. Bolter, B. Komodi, Immersion handbook, 240 (2009)

8. A. Aliev, N. Kazhe, Biligal education: theory and practice, 384 (2005)

9. On the state of education in the state (Crimean Tatar, Ukrainian) languages and the study of native languages in the educational organizations of the Republic of Crimea in the 2017/2018 academic year [Electronic resource]: URL:https://monm.rk.gov.ru/ru/structure/210

10. A.I. Prigozhin, Disorganization: causes, kinds, overcoming, 402 (2007) 